\title{
Mobilization of Arsenic in Groundwater in the Southern Hanoi City (Vietnam) as Studied by Isotopic and Related Techniques
}

\author{
Dang Duc Nhan ${ }^{1 *}$, Doan Van Canh ${ }^{2}$, Pham Quy Nhan ${ }^{3}$, Nguyen Thi Thanh Thuy ${ }^{4}$, \\ Dinh Thi Bich Lieu ${ }^{5}$, Vo Thi Anh ${ }^{5}$, Dang Anh Minh ${ }^{5}$ \\ ${ }^{1}$ Vietnam Atomic Energy Institute, Hanoi, Vietnam; ${ }^{2}$ Vietnam Association of Hydrogeology, Hanoi, Vietnam; ${ }^{3}$ Center for Water \\ Resources Management, Hanoi, Vietnam; ${ }^{4}$ Hanoi University of Mining and Geology, Hanoi, Vietnam; ${ }^{5}$ Institute for Nuclear Science \\ and Technology, Hanoi, Vietnam. \\ Email: *dangducnhan50@gmail.com
}

Received May $30^{\text {th }}, 2013$; revised June $30^{\text {th }}, 2013$; accepted July $11^{\text {th }}, 2013$

Copyright (C) 2013 Dang Duc Nhan et al. This is an open access article distributed under the Creative Commons Attribution License, which permits unrestricted use, distribution, and reproduction in any medium, provided the original work is properly cited.

\begin{abstract}
Sixteen samples of surface and groundwater from the most southern part of the Hanoi city (Vietnam) has been taken and analyzed for the soluble major ions, namely $\mathrm{Na}^{+}, \mathrm{K}^{+}, \mathrm{NH}_{4}^{+}, \mathrm{Ca}^{2+}, \mathrm{Mg}^{2+}, \mathrm{Cl}^{-}, \mathrm{NO}_{3}^{-}, \mathrm{NO}_{2}^{-}, \mathrm{SO}_{4}^{2-}$, and arsenic as well as molybdenum content along with isotopic composition of deuterium and oxygen $\left(\delta^{2} \mathrm{H}\right.$ and $\left.\delta^{18} \mathrm{O}\right)$, tritium activity, and $\delta^{13} \mathrm{C}$ in DIC. The stable isotopic composition of groundwater indicates the water in that area is recharged from the local meteoric and the Red River's water sources. The mean residence time of the groundwater should be before 60-ies of the past century as its ${ }^{3} \mathrm{H}$ activity ranged from LOD of the analytical technique (0.4 TU) to $2.1 \mathrm{TU}$ only implying that As would not be related to its recent application. The concentrations of As in the water samples is weakly correlated with those of $\mathrm{Fe}^{2+}\left(\mathrm{R}^{2}=0.08\right)$ but it strongly did with the concentrations of bicarbonate $\left(\mathrm{R}^{2}=0.80\right)$. Thus, bicarbonate seems to liberate As adsorbed on hydrous ferric oxides (Hfo) into water through the displacement mechanism. The surface adsorption-desorption of As could be proven by a strong correlation between As and Mo concentrations $\left(\mathrm{R}^{2}=0.77\right)$. The bicarbonate formation in groundwater was thought to be, partly, due to the bio-mineralization of natural organic matter (NOM) by bacteria followed by the dissolution of calcite and/or dolomite present in the sediments. Evidence for the NOM bio-mineralization was found in the close relationship between $\delta^{13} \mathrm{C}$ and the concentration of bicarbonate in water. Therefore, the mobilization of As in groundwater of bicarbonate type in the southern part of Hanoi city seems to be not only due to the reductive dissolution of the Hfo but the bicarbonate displacement also should be considered.
\end{abstract}

Keywords: Arsenic Mobilization; Isotopic Technique; Groundwater; Nom Bio-Mineralization; As-Bicarbonate Displacement

\section{Introduction}

The arsenic contamination at a high level in groundwater in the Hanoi city (Vietnam) has, for the first time, been reported by Berg et al. [1]. Since that time, other Vietnamese as well as foreign scientists have widen their survey for the As contamination in groundwater in the Holocene aquifer in other provinces of the country, e.g. Ha Nam [2], Phu Tho [3] provinces. Agusa and his coworkers [4] has monitored and evaluated the health risk of As as well as other heavy metals like $\mathrm{Cd}, \mathrm{Hg}, \mathrm{Pb}$ in

*Corresponding author. groundwater to the population of the Hanoi city. Several other studies $[5,6]$ were dealt with the technologies for the As removal from groundwater contaminated with As of higher than $10 \mu \mathrm{g} \cdot \mathrm{L}^{-1}$.

Recently, Do Van Binh [7] has summarized the trend of As distribution in groundwater in the Red River plain, northern Vietnam. According to the Binh's hypothesis, groundwater in the Quaternary sediments with silty clay and plant remains or peat usually contains high concentration of As.

Arsenic in groundwater was said to be of geogenic origin. This means that the presence of As in groundwa- 
ter is a consequence of either chemical or physico-chemical or biochemical or all of those processes resulting in the release of the constituent from sediments into the water under certain conditions. These processes include: 1) oxidative dissolution of arsenic containing minerals like arsenopyrite (FeAsS) [8]; 2) reductive dissolution of As adsorbed onto the surface of hydrous ferric oxide (Hfo) by natural organic matters (NOM) [9]; 3) bio-reductive dissolution of the Hfo by bacteria like Geospirillum barnesii [10]; and 4) bicarbonate displacement of As adsorbed onto the surface of the Hfo [11]. Luzi [5] and Ha [6] suggested that As in groundwater in the Hanoi area is resulted from the reductive dissolution of Hfo by NOM.

The purpose of this study is to investigate in more detail the mechanism of the As release in groundwater in the Hanoi city area where drinking water for more than 3 million habitants is supplied from the groundwater source only. The study area was Thanh Tri-a southern most district of the city where As in groundwater in almost all the wells is well above the admissible level set up by the Healthcare Ministry of Vietnam of $10 \mu \mathrm{g} \cdot \mathrm{L}^{-1}$. In addition to the conventional techniques, isotopic technique has, for the first time in Vietnam, been applied for this investigation.

\section{Materials and Methods}

\subsection{Sampling Locations and Sampling Method}

The study area is in Thanh Tri district and Figure 1 shows a map of the sampling locations. There are 16 water samples have been taken for the study during December 2009-March 2010. It includes 8 groundwater samples from upper and lower Holocene aquifers within the National Groundwater Monitoring Network, 3 samples of sediment pore water from the Red River's bank, 3 sam ples

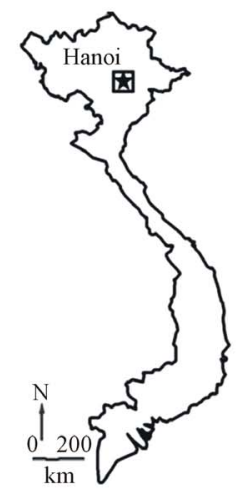

(a)

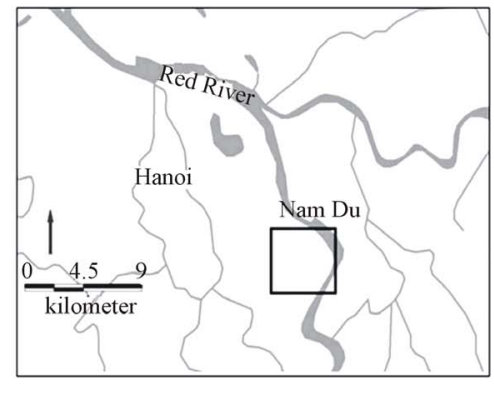

(b) of surface water from ponds around the monitoring wells and 2 samples from private wells of the local farmers.

The water in the wells has been flashed out till its temperature as well as other physico-chemical parameters like $\mathrm{pH}$, electric conductivity (EC), dissolved oxygen (DO) and redox potential (Eh) were constant. All these parameters were measured using respective probes which have been calibrated in the laboratory. The alkalinity of the samples, expressed in mg of $\mathrm{HCO}_{3}^{-} \mathrm{L}^{-1}$, was determined by titration of water samples with $\mathrm{H}_{2} \mathrm{SO}_{4} 0.2 \mathrm{~N}$ (PA grade, Merck, Germany) using a titrator device (Hach, USA) on the field. $500 \mathrm{ml}$ of water was filtered through $0.45 \mu \mathrm{m}$ nucleopore filters then the filtered sample was split into two parts. One part was stabilized with $\mathrm{HNO}_{3} 6 \mathrm{M}$ (PA grade, Merck, Germany) to $\mathrm{pH} 2$ for further analysis for major cations and heavy metals, but another part was not acidified serving for the analysis for major anions. Another $500 \mathrm{ml}$ of water without filtration was siphon into HDPE bottles of $500 \mathrm{ml}$ capacity. The bottles were filled to capacity with water to avoid isotopic exchange between the samples and atmospheric moisture. These samples will be used for the determination of tritium $\left({ }^{3} \mathrm{H}\right)$ activity and composition of deuterium $\left(\delta^{2} \mathrm{H}\right)$ and oxygen $18\left(\delta^{18} \mathrm{O}\right)$. Dissolved inorganic carbon (DIC), mainly in the form of bicarbonate was precipitated from the samples by a saturated $\mathrm{BaCl}_{2}$ solution at a $\mathrm{pH}>10$ in the field in a special device [12]. The $\mathrm{BaCO}_{3}$ precipitate was decanted from the supernatant and sealed off in bottles to avoid isotopes exchange between carbonate and carbon dioxide in the atmosphere.

\subsection{Geology of the Study Area}

The stratum of the study area is floodplain sedimentary.

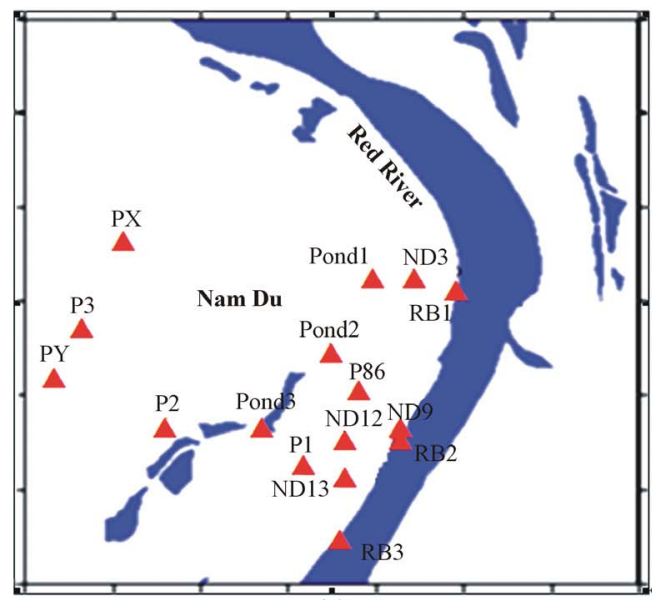

(c)

Figure 1. Map of the terrestrial territory of Vietnam (a), the larger Hanoi city (b) and the study area: Nam Du in Thanh Tri district (c) with sampling points (triangle and red colour points). The wells ID are described in details in Table 1. 
Sediment profile showed that the top layer with a depth up to $4 \mathrm{~m}$ from the surface is silty clay with gray yellowish and gray brownish colour mixed with plant remains. From the depth of $4 \mathrm{~m}$ to $17 \mathrm{~m}$ it is fine sand mixed with coarse sand, gravel and cobble of gray yellow colour. From $17 \mathrm{~m}$ to $37 \mathrm{~m}$ depth, there are cobble, gravel and small amount of fine sand.

\subsection{Sample Treatment and Analytical Techniques}

In the laboratory, the collected samples were processed for the ${ }^{3} \mathrm{H}$ enrichment by electrochemical method and measurement for its activity following a procedure developed by [13]. The limit of detection (LOD) of the method is $0.4 \mathrm{TU}\left(1 \mathrm{TU}=1\right.$ atom of ${ }^{3} \mathrm{H}$ in $10^{18}$ water molecules) and the accuracy of the procedure is better than $10 \%$ as checked with VSMOW standards.

Stable isotopes composition of water $\left(\delta^{2} \mathrm{H}, \delta^{18} \mathrm{O}\right)$ and carbon in DIC $\left(\delta^{13} \mathrm{C}\right)$ was analyzed using a Micromass IsoPrime mass spectrometer (GV Instruments, UK) equipped with EuroVector elemental analyzer (EA, Italy). The delta notation is defined as follows:

$$
\begin{aligned}
\delta^{2} \mathrm{H} & =\left(\frac{\mathrm{R}_{2 \mathrm{H}_{\text {sample }}}}{\mathrm{R}_{2 \mathrm{H}_{\text {std }}}}-1\right) \cdot 1000, \% 0 \\
\delta^{18} \mathrm{O} & =\left(\frac{\mathrm{R}_{18 \mathrm{O}_{\text {sample }}}}{\mathrm{R}_{18 \mathrm{O}_{\text {std }}}}-1\right) \cdot 1000, \% 0 \\
\delta^{13} \mathrm{C} & =\left(\frac{\mathrm{R}_{13 \mathrm{C}_{\text {sample }}}}{\mathrm{R}_{13 \mathrm{C}_{\text {std }}}}-1\right) \cdot 1000, \% 0
\end{aligned}
$$

where $\mathrm{R}$ is the isotopic ratio of ${ }^{2} \mathrm{H},{ }^{18} \mathrm{O}$ and ${ }^{13} \mathrm{C}$ compared to ${ }^{1} \mathrm{H},{ }^{16} \mathrm{O}$ and ${ }^{12} \mathrm{C}$ in sample and standards (std).

Arsenic and molybdenum (Mo) was analyzed on an ICP-MS (Aligent 7500, USA). The major cations and anions such as $\mathrm{Na}^{+}, \mathrm{K}^{+}, \mathrm{NH}_{4}^{+}, \mathrm{Mg}^{2+}, \mathrm{Ca}^{2+}, \mathrm{Cl}^{-}, \mathrm{Br}^{-}$ $\mathrm{NO}_{2}^{-}, \mathrm{NO}_{3}^{-}, \mathrm{SO}_{4}^{2-}$ were analyzed on an ion chromatograph, IC DIONEX 600 (USA).

A QA/QC program for the isotopes analysis was applied by the sample split method. Several water samples were split into three parts. One part was sent to the IAEA's Isotope Hydrology laboratory (Vienna), another to the Isotope Hydrology laboratory of the Bhabha Atomic Research Center (BARC, India) and the third was kept in the Hanoi Isotope Hydrology laboratory for parallel analysis. The standard deviation of the analyses from the tree laboratories was within acceptable $( \pm 5 \%)$ range. The standards used for the water stable isotopes analysis are VSMOW but for the $\delta^{13} \mathrm{C}$ is Vienna Pee Dee Belemnite (VPDB). Both are from IAEA, Vienna, Austria.
A QA/QC procedure applied for water chemistry analysis was the yearly participation in the inter-laboratory comparison exercise organized by the Global Environmental Monitoring System (GEMS). The Z-score values for analytes of concern were less than 2 indicating an acceptable accuracy of the analyses.

\section{Results and Discussions}

\subsection{Results}

Table 1 presents the analytical results of water quality and isotopic compositions of the study samples. Results from field measurements showed that groundwater from all of the studied wells is warmer as compared to the surface water of the ponds or the River. The temperature of groundwater was ranging from $25.5^{\circ} \mathrm{C}$ to $26.7^{\circ} \mathrm{C}$, i.e. at $2^{\circ} \mathrm{C}-4^{\circ} \mathrm{C}$ higher than that of water in ponds and the Red River $\left(21.6^{\circ} \mathrm{C}-24.9^{\circ} \mathrm{C}\right)$. This is due to the evaporation of surface water during the dry season. The $\mathrm{pH}$ of groundwater was in between 6.3 to 7.1 that in $1-2 \mathrm{pH}$ unit lower than the $\mathrm{pH}$ of water from the same River and ponds. Water in the study area is bicarbonate of $(\mathrm{Na}, \mathrm{Ca}$, $\mathrm{Mg}$ ) type with a high concentration of bicarbonate ranging from 2 to $12 \mathrm{mmol} \cdot \mathrm{L}^{-1}$. Dissolved oxygen (DO) in groundwater was very low, at a level of the LOD of the equipment $\left(0.1 \mathrm{mg} \cdot \mathrm{L}^{-1}\right)$ that makes the environment of the water to be reductive with an Eh range of -40 to $-160 \mathrm{mV}$. Meantime, Eh of the surface water is positive and ranging from 135 to $190 \mathrm{mV}$.

The reductive environment in the aquifer makes sulphate to be negligible and it could be found only in the surface water with a concentration of 0.04 to $0.36 \mathrm{mmol} \cdot \mathrm{L}^{-1}$. In groundwater neither nitrite nor nitrate was found but there was only ammonium of $0.8-3.5 \mathrm{mmol} \cdot \mathrm{L}^{-1}$ that fairly exceeded the admissible limit set up by the Healthcare Ministry of Vietnam [14] of $0.17 \mathrm{mmol} \cdot \mathrm{L}^{-1}$ as $\mathrm{NH}_{4}^{+}$. In fact, ammonium is another contamination issue in groundwater in the southern part of the Hanoi city. The high concentration of ammonium in the groundwater might be resulted from the bio-mineralization of natural organic matters (NOM) in the water under anaerobic conditions [15]. The Ca concentration in all the groundwater samples was much higher than that calculated from the equilibrium dissolution of calcite $([\mathrm{Ca}]=0.06$ $\mathrm{mmol} \cdot \mathrm{L}^{-1}$, at $\mathrm{pH} \approx 7$ ). Thus, the bio-mineralization of NOM in the water definitely is an important process that could add supplementary carbon dioxide to dissolve the minerals. In this study, dolomite seems to co-exist with calcite as the $[\mathrm{Ca}]$ and $[\mathrm{Mg}]$ concentrations in the water samples are fairly dependent on each other.

Arsenic concentrations in groundwater were ranged from 0.5 to $5.3 \mu \mathrm{mol} \cdot \mathrm{L}^{-1}(1 \mu \mathrm{mol}=75 \mu \mathrm{g})$ (Table 1) that well exceeded the allowable level set up by the Health 
Table 1. Selected parameters of water samples collected from the Nam Du area (southern most Hanoi city, Vietnam) in the dry season of the 2006 .

\begin{tabular}{|c|c|c|c|c|c|c|c|c|}
\hline Sample ID & Depth ( m) & $\mathrm{pH}$ & Eh (mV) & $\mathrm{Fe}^{2+}\left(\mathrm{mg} \cdot \mathrm{L}^{-1}\right)$ & $\mathrm{As}_{\mathrm{tot}}\left(\mu \mathrm{g} \cdot \mathrm{L}^{-1}\right)$ & $\mathrm{NH}_{4}^{+} \quad\left(\mathrm{mg} \cdot \mathrm{L}^{-1}\right)$ & $\mathrm{HCO}_{3}^{-}\left(\mathrm{mg} \cdot \mathrm{L}^{-1}\right)$ & $\operatorname{Mo}\left(\mathrm{mg} \cdot \mathrm{L}^{-1}\right)$ \\
\hline Pond 1 & 0 & 8.21 & 109 & 0.08 & 4.9 & 1.60 & 211 & 1.0 \\
\hline Pond 2 & 0 & 7.40 & 131 & 0.03 & 2.6 & 0.41 & 160 & 0.3 \\
\hline Pond 3 & 0 & 7.54 & 141 & 0.06 & 1.9 & 2.40 & 147 & 0.9 \\
\hline PX & 70 & 6.31 & -42 & 2.10 & 18.7 & 3.2 & 222 & 0.4 \\
\hline PY & 23 & 6.68 & -132 & 12.6 & 264 & 34.7 & 696 & 10.3 \\
\hline RB 1 & 0.3 & 7.08 & 180 & 0.08 & 2.6 & 0.45 & 139 & 2.4 \\
\hline RB 2 & 0.3 & 7.30 & - & 0.30 & 0.4 & 1.2 & 220 & 0.3 \\
\hline RB 3 & 0.5 & 7.18 & -87 & 1.4 & 173 & 5.1 & 442 & 5.5 \\
\hline $\mathrm{P} 1$ & 57 & 7.11 & -159 & 10.6 & 257 & 12.7 & 450 & 3.8 \\
\hline $\mathrm{P} 2$ & 26 & 7.35 & -128 & 2.3 & 18 & 20.7 & 353 & 0.5 \\
\hline P3 & 21 & 6.29 & -81 & 37.3 & 134 & 14.6 & 9.8 & 0.6 \\
\hline P 86 & 57 & 6.95 & -125 & 7.0 & 312 & 9.2 & 467 & 5.6 \\
\hline ND 3 & 60 & 6.65 & -138 & 9.2 & 83 & 4.3 & 332 & 1.5 \\
\hline ND 9 & 60 & 6.35 & -94 & 11.7 & 83 & 8.6 & 349 & 1.1 \\
\hline ND12 & 65 & 7.10 & -124 & 3.5 & 44 & 1.8 & 190 & 0.4 \\
\hline ND 13 & 60 & 6.86 & -13 & 8.2 & 81 & 5.6 & 239 & 0.3 \\
\hline
\end{tabular}

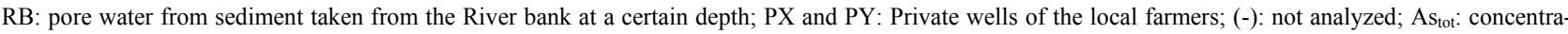
tion of total arsenic $[\mathrm{As}(\mathrm{V})+\mathrm{As}(\mathrm{III})]$.

care Ministry of Vietnam for drinking water $(0.13$ $\left.\mu \mathrm{mol} \cdot \mathrm{L}^{-1}\right)$.

Stable isotopes composition of groundwater $\left(\delta^{2} \mathrm{H}\right.$ vs. $\delta^{18} \mathrm{O}$, Figure 2) in the study area clearly showed that the groundwater in the study area is recharged from the local meteoric and the Red River's sources. From Figure 2 one can see all the points of the $\delta^{2} \mathrm{H}$ vs. $\delta^{18} \mathrm{O}$ for the water samples studied are located in between the local me-

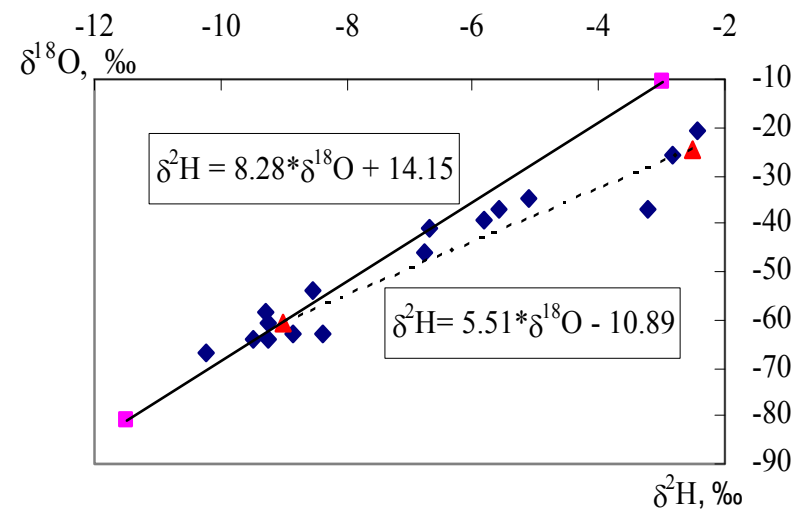

Figure 2. Stable isotopes composition of water samples (dark colour points) and precipitation (solid line) and water from the Red River (dot line). teoric line $\left(\delta^{2} \mathrm{H}, \%=8.28 * \delta^{18} \mathrm{O}+14.25\right)$ and the line of water of the Red River $\left(\delta^{2} \mathrm{H}, \%_{0}=5.51 * \delta^{18} \mathrm{O}-10.89\right)$. Both were obtained by the consecutive monitoring from the 2002 year till now on the monthly basic [16].

The result of the ${ }^{3} \mathrm{H}$ analysis showed that the resident time of groundwater in the study area could be comparable to the age of or before the 60 -ies of the past century as the activity of ${ }^{3} \mathrm{H}$ varies from the LOD of the analytical method to $2.1 \mathrm{TU}$, while that of the surface water is in a range of $3.6-4.2 \mathrm{TU}$. This implies that As in groundwater could not be attributed to its recent application. In other words, the contaminant could, likely, not originate from anthropogenic but from geogenic sources.

At first look, the concentration of As in the water samples is dependent on the concentration of ferrous ion, however the correlation of the two constituents is very poor, $\mathrm{R}^{2}=0.08$ (Figure 3 ). This means that the high concentration of As in groundwater in the study area could not be explained only based on the reductive dissolution of As adsorbed on Hfo by NOM or by the biological dissolution of NOM. There the displacement of As associated with Hfo by bicarbonate might be the third mechanism that definitely affects the mobilization of As in the ground water of the bicarbonate type [11]. 
An evidence for the contribution of the As-bicarbonate displacement into As mobilization in groundwater in the study area is a strong correlation between $\mathrm{As}$ and $\mathrm{HCO}_{3}^{-}$ $\left(\mathrm{R}^{2}=0.80\right.$, Figure 4). An additional evidence for the As-bicarbonate displacement mechanism for the As mobilization in groundwater of the study area is a fair correlation between As and Mo concentrations $\left(\mathrm{R}^{2}=0.77\right.$, Figure 5). Dowling and his co-workers [15] has shown that molybdate $\left(\mathrm{Mo}_{2} \mathrm{O}_{7}^{2-}\right)$ as a redox oxy-anion could play an important role in the adsorption-desorption processes on the surface of Hfo and it could be a reagent controlling the release of As into groundwater through the ion exchange between molybdate, bicarbonate and arsenic.

The bicarbonate formation in the groundwater was thought to be as a result of the calcite and/or dolomite dissolution by the hydrate carbon dioxide. This fact is proven by a close relationship between the $\left[\mathrm{HCO}_{3}^{-}\right]$and $\{[\mathrm{Ca}]+[\mathrm{Mg}]\}\left(\mathrm{R}^{2}=0.76\right.$, Figure 6). The source of the carbon dioxide could be, first, from the atmosphere dissolved in the recharged water which is depleted by ${ }^{13} \mathrm{C}$ to

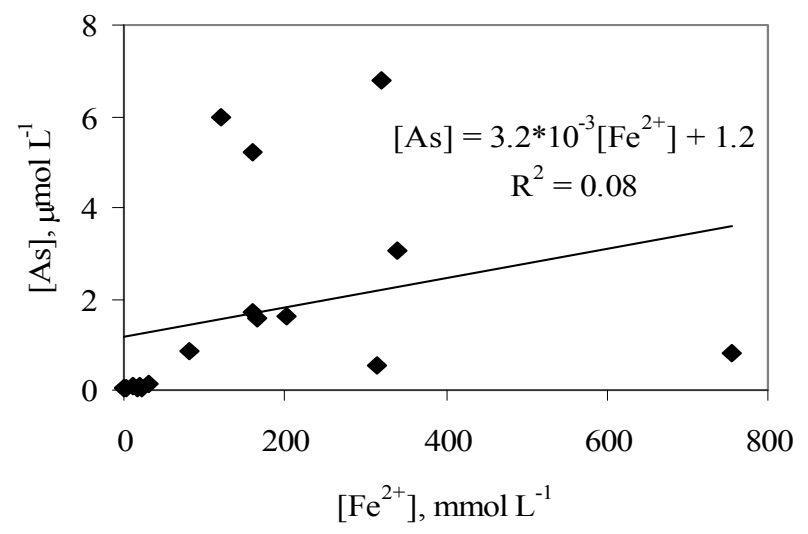

Figure 3. Correlation of $\mathrm{As}$ and $\mathrm{Fe}^{2+}$ concentrations in water samples of the study area.

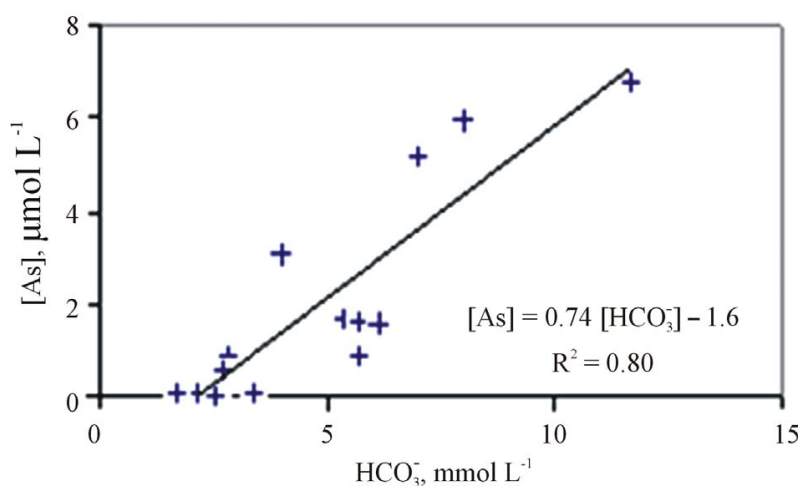

Figure 4. Correlation between arsenic and bicarbonate concentrations in water samples of the study area.

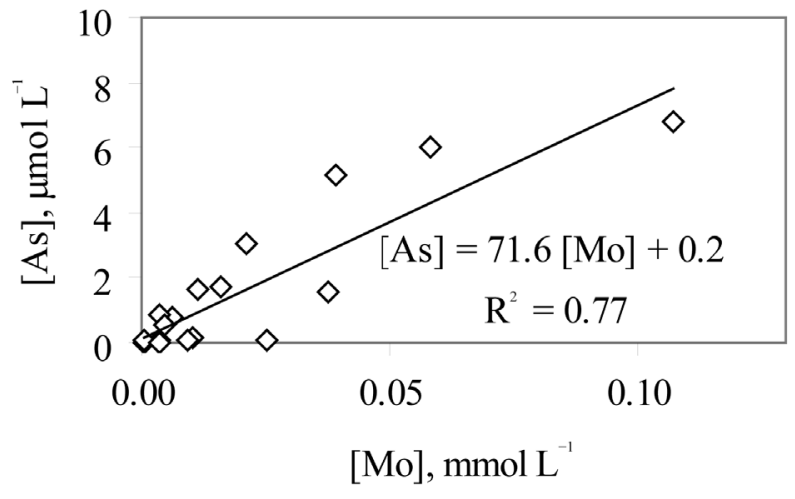

Figure 5. Correlation between arsenic and molybdenum concentrations in water samples of the study area.

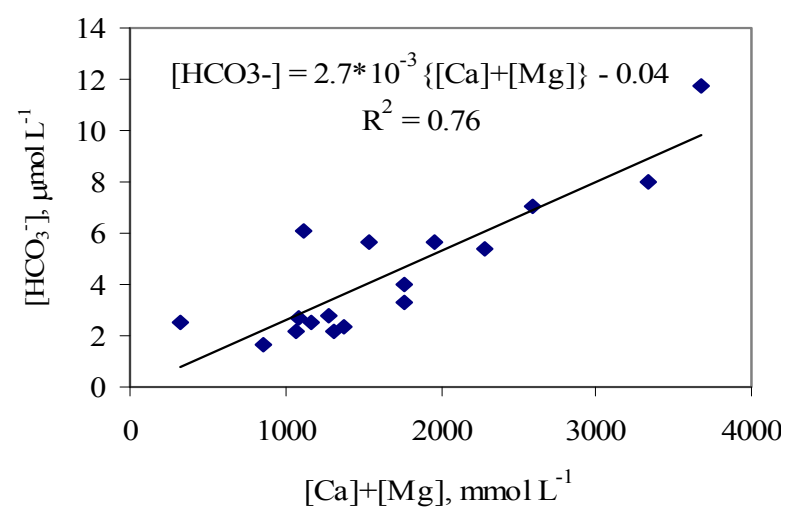

Figure 6. Bicarbonate in groundwater originates from the calcite/biotite dissolution by hydrate carbon dioxide formed from bio-mineralization of NOM.

a level of $-7 \%$ compared to the PDB standard [11]. The second source of the $\mathrm{CO}_{2}$ would be from the bio-degradation of NOM by bacteria.

In the tropical zone with vegetation of $\mathrm{C} 3$ plants the bio-degradation of the NOM could lead to the depletion of ${ }^{13} \mathrm{C}$ to $-24 \%$ [11]. The hydrate carbon dioxide from the two sources will participate in the dissolution of calcite possessing $\delta^{13} \mathrm{C}=0 \%$ vs. PDB (by definition) resulted in the enrichment of ${ }^{13} \mathrm{C}$ in bicarbonate [11]. Figure 7 depicts the dependence of the $\delta^{13} \mathrm{C}$ and $\left[\mathrm{HCO}_{3}^{-}\right]$in the study water samples. This figure shows the enrichment of ${ }^{13} \mathrm{C}$ as a result of the calcite and/or biotite dissolution. The relationship of $\delta^{13} \mathrm{C}$ vs. $\left[\mathrm{HCO}_{3}^{-}\right]$is described by an equation $\delta^{13} \mathrm{C}, \%=1.98 *\left[\mathrm{HCO}_{3}^{-}\right]-23.81, \mathrm{R}^{2}=$ 0.74 .

\subsection{Discussion}

Results of this study show an important role of bacteria in the mobilization of As in groundwater under anaerobic conditions. A strong correlation between $[\mathrm{As}]$ and $\left[\mathrm{NH}_{4}^{+}\right]$ (Figure not shown here) is proven the said fact as ammo- 


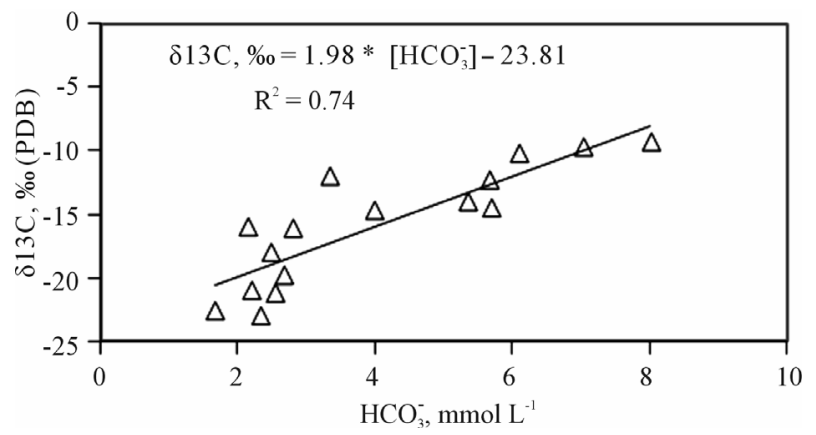

Figure 7. Composition of $\delta^{13} \mathrm{C}$ isotope in bicarbonate is enriched with the increase of the constituent concentration.

nium cation could not participate in the adsorption-desorption on the surface of Hfo but it mainly could be related to the ammonification of the Hfo. AcArthur [10] mentioned that the biological activities are the driving force governing the reductive dissolution of Hfo to release As and form ammonium as well as methane. Laverman and his co-workers [17] informed that the Geospillium barnesii is capable of the reduction of both $\mathrm{Fe}(\mathrm{III})$ and $\mathrm{As}(\mathrm{V})$ thus it could retain the constituents in water but not allow it to re-adsorb on the surface of Hfo. On the other hand, in our study a strong correlation between [As] and [Mo] has been revealed (Figure 5). The oxy-anion molybdate is sensitive to the surface adsorption-desorption similar to arsenate and arsenide [15]. Thus, the close correlation of the [As] and [Mo] could be an evidence for the adsorption-desorption of As on the surface of Hfo. Bicarbonate was thought to be the reagent that could displace arsenide and arsenate as well as molybdate in the bicarbonate type of groundwater that are abundant in the southern part of the Hanoi city. The bicarbonate formation in groundwater of the study area could, possibly, be described by the following reactions.

$$
\mathrm{CH}_{2} \mathrm{O}+2 \mathrm{H}_{2} \mathrm{O} \stackrel{\text { enzyme }}{\longrightarrow} \mathrm{HCO}_{3}^{-}+5 \mathrm{H}^{+}
$$

where the $\mathrm{CH}_{2} \mathrm{O}$ stands for natural organic matter dissolved in water (see, e.g. ref. [11]).

$$
\mathrm{HCO}_{3}^{-}+\mathrm{CaCO}_{3}+\mathrm{H}^{+}=\mathrm{Ca}\left(\mathrm{HCO}_{3}\right)_{2}
$$

and

$$
\begin{gathered}
2 \mathrm{HCO}_{3}^{-}+\mathrm{CaMg}\left(\mathrm{CO}_{3}\right)_{2}+2 \mathrm{H}^{+} \\
=\mathrm{Ca}\left(\mathrm{HCO}_{3}\right)_{2}+\mathrm{Mg}\left(\mathrm{HCO}_{3}\right)_{2} \\
\mathrm{Ca} / \mathrm{Mg}\left(\mathrm{HCO}_{3}\right)_{2}=\mathrm{Ca}^{2+}+\mathrm{Mg}^{2+}+4 \mathrm{HCO}_{3}^{-}
\end{gathered}
$$

Based on proposed reactions, one could also explain why the $\mathrm{pH}$ value of groundwater in the study area is lower as compared to that of the surface water and how the ${ }^{13} \mathrm{C}$ isotope in DIC is enriched when the bicarbonate concentration in water increases (Figure 7). According to the reaction (4) five moles of acid could be formed when one mole of NOM was decomposed. The NOM decomposition made $\delta^{13} \mathrm{C}$ of $-24 \%$ vs. PDB to be enriched by the dissolution of calcite/dolomite (reactions 5 and 6) possessing $\delta^{13} \mathrm{C}$ nearly to $0 \%$ vs. PDB.

\section{Conclusions}

Groundwater in the Thanh Tri-a southern most district of the Hanoi city is bicarbonate $(\mathrm{Na}, \mathrm{Ca}, \mathrm{Mg}$ ) type with the $[\mathrm{Ca}]$ and $[\mathrm{Mg}]$ concentration much higher than those calculated from the equilibrium dissolution of calcite/ biotite under the neutralized conditions. Groundwater in most of wells of the monitoring network contains As with a concentration in 4 to 28 times higher than the admissible level set up by the Healthcare Ministry of Vietnam at $10 \mu \mathrm{g} \cdot \mathrm{L}^{-1}$. Although there was no chance to speciation the proportion of $\mathrm{As}(\mathrm{V})$ and $\mathrm{As}(\mathrm{III})$ in the water samples, however, based on the Eh-pH diagram of As [11] one could predict that almost $100 \%$ of As in groundwater of the study area be in the As(III) form. The mobilization of As in groundwater was thought to be governed by the biological activities under anaerobic conditions. There bacteria could mineralize NOM in water to enhance the increase of bicarbonate concentration and displacement for arsenide adsorbed on the surface of Hfo. Moreover, bacteria could also reduce Fe(III) and $\mathrm{As}(\mathrm{V})$ and stabilize As(III) in the groundwater.

Investigation into geohydrological and biological controlling processes of arsenic release in groundwater in the Red River and Me Kong River plains is continued conducting under the Scientific Research Theme entitled: "Study to determine the criteria and zoning for sustainable exploitation and protection of groundwater resource in the Red River and Me Kong River deltas" encoded KC.08.06/11-15 supported by the Ministry of Scence and Technology of Vietnam.

\section{Acknowledgements}

The authors wish to thank Dr. Nguyen Thi Kim Dung and Mr. Pham Ngoc Khai from the Center for Analytical Chemistry and Environment, Institute for Technology of Rare and Radioactive Elements, VAEI for their analyses for heavy metals in the water samples studied.

\section{REFERENCES}

[1] M. Berg, H. C. Tran, T. C. Nguyen, H. V. Pham, R. Schetenleib and W. Riger, "Arsenic Contamination of Groundwater and Drinking Water in Vietnam: A Human Health Threat," Environmental Science and Technology, Vol. 35, No. 13, 2001, pp. 2621-2626. doi:10.1021/es010027y

[2] P. K. Quoc, "Investigation into the Sources and Distribution of Arsenic in the Holocene Aquifer in the Ha Nam 
Province, Vietnam," M.Sc. Thesis, Hanoi University of Mining and Geology, Hanoi, 2006. (in Vietnamese)

[3] T. C. But, "Investigation into the Trend of Arsenic Pollution in Groundwater within Phu Tho Province. Measures to Reduce the Health Risk to the Human Health Due to the Consumption of Water Contaminated with Arsenic," M.Sc. Thesis, Hanoi University of Mining and Geology, Hanoi, 2006. (in Vietnamese)

[4] T. Agusa , T. Kunito , J. Fujihara , T. B. Minh, P. T. K. Trang, H. Itawa, A. Subramanian, P. H. Viet and S. Tanabe, "Contamination by Arsenic and Other Trace Elements in Tube-Wells Water and Its Risk Assessment to Human in Hanoi, Vietnam," Environmental Pollution, Vol. 139, No. 2, 2006, pp. 330-339.

[5] S. Luzi, M. Berg, P. T. T. Trang, B. H. Nhat and P. H. Viet, "A Sand Filtration Solution for the Arsenic Removal from Tube-Well Groundwater at the Family Scale," Proceeding of the 3rd Conference of Science and Technology for the Environment and Sustainable Development, Hanoi University of Natural Sciences Press, Hanoi, 2004, pp. $52-55$.

[6] C. T. Ha , L. V. Chieu, D. V. Ve , V. N. Duy, T. P. Lai, M. Berg and U. von Gunten, "Arsenic Removal from Groundwater by Iron Co-precipitation in Contact Filter," Proceeding of the 3rd Conference of Science and Technology for the Environment and Sustainable Development, Hanoi University of Natural Sciences Press, Hanoi, 2004, pp. 56-59.

[7] D. V. Binh, "The Formation and Distribution Trend of Arsenic in Groundwater of the Quaternary Aquifers. Measures for Reducing the Risk of the Arsenic Contamination to the Water Quality," Ph.D. Thesis, Hanoi University of Mining and Geology, Hanoi, 2007.

[8] P. L. Smedly and D. G. Kinniburgh, "A Review of the Sources, Behaviour and Distribution of Arsenic in Natural Water," Applied Geochemistry, Vol. 17, No. 5, 2002, pp. 517-568. doi:10.1016/S0883-2927(02)00018-5

[9] P. Ravencroft, J. M. McArthur and B. A. Hoque, "Geochemical and Paleohydrological Controls on Pollution of Groundwater by Arsenic," In: W. R. Chappell, Ed., Arsenic Exposure and Health Effect IV, Elsevier, Amsterdam,
2001.

[10] J. M. McArthur, P. Ravencroft and M. F. Thirlwall, “Arsenic in Groundwater: Testing Pollution Mechanisms for Sedimentary Aquifers in Bangladesh," Water Resources Research, Vol. 37, No. 1, 2001, pp. 109-117. doi:10.1029/2000WR900270

[11] C. A. Appello and D. Postma, "Geochemistry, Groundwater and Pollution," 2nd Edition, Balkema Publisher, Amsterdam, 2005.

[12] IAEA, International Atomic Energy Agency, "Sampling Procedure for Hydrology," Water Resources Programme, IAEA, Vienna, 2001.

[13] D. T. B. Lieu, "Concentration of Tritium in Precipitation over the Hanoi City," Final Report to Ministry of Science and Technology of Vietnam of "the Result of Research Theme on the Development of a Procedure for Electrochemical Enrichment followed by Low Background Liquid Scintillation Counting for Tritium in Water Samples", Hanoi, 2004. (in Vietnamese)

[14] QCVN 02: 2009/BYT, "National Technical Regulation on Domestic Water Quality," Ministry of Healthcare of Vietnam, Hanoi, 2009.

[15] C. B. Dowling, R. J. Poreda, A. R. Basu, S. L. Peter and P. K. Aggarwal, "Geochemical Study of Arsenic Release Mechanisms in Bengal Basin Groundwater," Water Resources Research, Vol. 38, No. 1, 2002, pp. 1-20. doi:10.1029/2001WR000968

[16] D. D. Nhan, T. Van Giap, D. T. B. Lieu, D. T. Loan, V. T. Anh, D. A. Minh, N. T. H. Thinh and D. D. Viet, "Arsenic Contaminated Groundwtaer in the Hanoi Area and Its Studies Using Isotopic Techniques," Country Report to the IAEA of the RAS/8/097 Project for Vietnam, Institute for Nuclear Science and Technology, Hanoi, 2004.

[17] A. M. Laverman, J. S. Blum, J. K. Schaefer, E. J. P. Phillips, D. R. Loveley and R. S. Oremland, "Growth of Strain SES-3 with Arsenate and Other Diverse Electron Acceptors," Applied Environmental Microbiology, Vol. 61, No. 10, 1995, pp. 3556-3561. 